\title{
On the cost of vertical migration: are feeding conditions really worse at greater depths?
}

\author{
M. WINDER*, M. BOERSMA ${ }^{\dagger \ddagger}$ AND P. SPAAK* \\ *Department of Limnology, EAWAG/ETH, Überlandstrasse, Dübendorf, Switzerland \\ +Max-Planck-Institut für Limnologie, Abteilung Ökophysiologie, Postfach, Plön, Germany \\ $\ddagger$ Alfred Wegener Institute for Polar and Marine Research, Biologische Anstalt Helgoland, Helgoland, Germany
}

\section{SUMMARY}

1. The ultimate explanation for diel vertical migration (DVM) of zooplankton is the avoidance of visual predation in surface waters. Studies on migrating zooplankton have shown that remaining in the cold and food-poor hypolimnion during the day, however, has demographic costs. Higher temperatures and greater food concentrations in the surface waters are thought to be the main reasons why Daphnia species move upwards at night.

2. In this study, we investigated the growth condition of daphniids raised on seston taken from different depths from a lake with and without a deep-water chlorophyll maximum. 3. Juvenile growth rates of Daphnia galeata $x$ hyalina from the lake without a deep-water chlorophyll maximum were similar for all treatments. After temperature correction, however, growth rates were significantly higher on seston taken from the surface layers. 4. In contrast, in the lake with the deep-water chlorophyll maximum, D. galeata growth rates were higher in deeper strata, even after temperature correction. Although this lake had a weak temperature gradient, D. galeata left the food-rich strata at night and migrated into the surface food-poor environment. Invertebrate predation and oxygen depletion are probably not the reasons for the nocturnal upward migration into the surface strata. Therefore, we assume that $D$. galeata migrates upwards to take advantage of higher temperatures. Using several temperature-egg-development models, we could not, however, fully explain this behaviour.

Keywords: Daphnia, food quality, growth rate, high-mountain lake, vertical migration

\section{Introduction}

The pelagic habitat of lakes is characterised by pronounced vertical gradients in light, temperature, resources, competition strength and predation risk (Zaret, 1980; DeMott \& Kerfoot, 1982; Geller, 1986). The vertical stratification of these factors strongly affects the vertical distribution of zooplankton. Many zooplankton species avoid the surface layers during daytime, migrating downward to deep layers and returning to surface waters at night (Gliwicz, 1986;

Correspondence and present address: Monika Winder, Department of Zoology, University of Washington, Box 351800, Seattle, WA 98195-1800, U.S.A. E-mail: mwinder@u.washington.edu
Stich, 1989; Ringelberg et al., 1991b). The reaction to relative changes in light intensity (secondary phototaxis) is the primary physiological mechanism underlying this diel vertical migration (DVM) behaviour (Ringelberg, 1999). Changes in DVM behaviour can be induced by chemical cues exuded from potential predators (for a review, see Pijanowska, Weider \& Lampert, 1993). The daytime distribution is determined largely by vertical differences in predation risk (i.e. juvenile fish) or by the deleterious effect of ultraviolet radiation (UVR) in surface waters and is often related to zooplankton body size, transparency and pigmentation (Ringelberg, 1999). It is generally accepted that DVM is an adaptive predator avoidance strategy (Lampert, 1993). However, migrating deeper 
into cold and food-poor waters has significant costs (Orcutt \& Porter, 1983; Gabriel \& Thomas, 1988). These costs are expressed as a reduction in somatic growth and egg production because of reduced temperature and food in the deep daytime refuge, thereby resulting in an overall reduced growth rate (Stich, 1989; Ringelberg et al., 1991a; Loose \& Dawidowicz, 1994). Hence, migrating species normally trade-off light-dependent mortality risks (i.e. visual hunting fish, UVR) against reduced growth to optimise their fitness (Ringelberg, 1999).

The nocturnal upward migration of zooplankton is usually explained by the higher food quantities and higher temperatures in surface waters (Lampert, 1989). However, little is known about how the quality of the food changes in the water column, and vertical distribution of food resources are seldomly measured in combination with migration patterns (but see Stich \& Lampert, 1981; Gliwicz \& Pijanowska, 1988; Schöps, 1999). Recent studies have demonstrated that resource availability may not necessarily be worse at greater depths (Williamson et al., 1996). This experimental study by Williamson et al. (1996) is one of the first to indicate that food availability can in fact be better in deeper layers compared with surface waters. Their study also showed that in many DVM studies, the reduced food effect in the deep-water daytime refuge might have been overestimated. Thus, low temperature, rather than food availability, may be the most important cost for animals that migrate downward and stay in dark daytime refuge, as was earlier suggested by Kerfoot (1985).

Some lakes have deep-water chlorophyll maxima, especially during the summer months (Fee, 1976; Tilzer \& Schartz, 1976; Williamson et al., 1996). For example, increased algal biomass in deeper strata is typical for alpine lakes and is attributed to higher nutrient availability and reduced solar radiation at depth (Tilzer \& Schartz, 1976). These deep-water chlorophyll maxima may be dominated by filamentous cyanobacteria or other low quality foods (Kasprzak et al., 2000), and hence chlorophyll or particulate organic carbon (POC) measurements may not be adequate indicators of food availability for zooplankton. Quantitative food measurements do not generally consider edibility, changes in quality (e.g. biochemical composition) or microbial communities that might change with depth (Uehlinger \& Bloesch, 1987; Bennett, Sanders \& Porter, 1990; Müller-Navarra
\& Lampert, 1996). The quality of natural seston as food for zooplankton can be highly variable and the importance of mineral and biochemical composition in algae for zooplankton growth is evident from recent studies (Boersma, Schöps \& McCauley, 2001; Elser, Hayakawa \& Urabe, 2001). An approach to quantify food quality is to raise zooplankton on natural seston and measure life-history traits (Boersma \& Vijverberg, 1995; Müller-Navarra \& Lampert, 1996).

Given the occurrence of deep-water chlorophyll maxima, we hypothesised that food conditions at depth in lakes with a deep chlorophyll maximum should be much better relative to those at the surface than in those lakes where these deep chlorophyll maxima are absent. This would imply that in lakes with a deep chlorophyll maximum, the effect of temperature as a cost should be more pronounced than in those lakes that do not have higher food levels at depth. Hence, we addressed the question whether the feeding conditions at greater depths are as good as in surface water in a lake with and without a deepwater chlorophyll maximum. Daphnia species were raised at a standard temperature on seston collected from different depths. Thus, any changes in lifehistory traits should be caused by differences in food availability and not temperature. In a lake with a deep-water chlorophyll maximum, we would expect better Daphnia growth conditions when raised on water taken from deep strata compared with surface strata. In contrast, in the lake without a deep-water chlorophyll maximum, we expect that growth conditions of the daphniids are better on water taken from the surface layers.

\section{Methods}

Field sampling

Two lakes differing in the distribution of algae over depth were sampled. The lake with a deep-water food maximum was the high-mountain lake Oberer Arosasee (Arosa, Switzerland; Winder \& Spaak, 2001). The lake without a deep-water food maximum was the lowland lake, Schöhsee (Plön, Germany; Lampert, 1988).

In the Oberer Arosasee, POC and particulate phosphorus $(\mathrm{P})$ samples were taken at six depths $(0,2.5,5$, $7.5,10$ and $12.5 \mathrm{~m}$ ) every third week during the open water period from May 1998 to October 2000 and once 
under the ice cover in winter (for analytical method, see Uehlinger et al., 1984). Phytoplankton samples were taken from the six depths from June to August 1998 every third week using a 5-L Schindler trap. In summer 1998, zooplankton was sampled weekly at mid-day and mid-night from three stations around the deepest part of the lake at $2.5-\mathrm{m}$ intervals from 0 to $12.5 \mathrm{~m}$ depth using a duo-closing net with $95-\mu \mathrm{m}$ mesh size (Bürgi, 1983). A total of $300 \mathrm{~L}$ per depth stratum was collected; samples per depth stratum were pooled.

In the Schöhsee, vertical profiles of POC and particulate $\mathrm{P}$ were measured fortnightly from April until October 1998 from 1, 5 and $12 \mathrm{~m}$ depth (for analytical method see Uehlinger et al., 1984). From June until August 1998 phytoplankton samples were taken fortnightly at 1,5 and $12 \mathrm{~m}$ depth. At the same dates, zooplankton was sampled from 1 to $12 \mathrm{~m}$ depth at 1-m intervals at mid-day and once in June and July at mid-night using a 23-L Schindler trap.

In both lakes, temperature was recorded from the surface to the bottom at 1-m intervals on each sampling occasion. For phytoplankton identification, $100 \mathrm{~mL}$ of lake water from each depth stratum were fixed with Lugol's solution and analysed with the Utermöhl settling technique (Rott, 1981). Biovolumes were estimated from cell dimensions and geometry; cell size and shape distinguished edible from inedible algal cells (Infante, 1973; Porter, 1973; Conover \& Mayzaud, 1984). Zooplankton samples were concentrated and preserved in $96 \%$ ethanol. At least 100 individuals of adult daphniids (if possible) were counted from each depth.

\section{Growth experiment under natural food conditions}

Using Daphnia from both lakes, we conducted two growth experiments during the summer (when vertical migration is strongest) in the laboratory with lake seston. For the Oberer Arosasee experiment we used a clone of Daphnia galeata, originating from this lake, and for the Schöhsee experiment a D. galeata $x$ hyalina clone, originally collected from nearby Lake Plußsee was used. The experiments were carried out in flowthrough chambers $(170 \mathrm{~mL})$ similar to those described by Lampert, Schmitt \& Muck (1988), with a flow rate of $40 \mathrm{~mL} \mathrm{~h}^{-1}$ and constant temperature conditions (Oberer Arosasee $18{ }^{\circ} \mathrm{C}$; Schöhsee $20^{\circ} \mathrm{C}$ ). Fresh water was collected from the lakes every morning: in the
Oberer Arosasee, with a deep-water chlorophyll maximum, at five depths $(1.3,3.8,6.3,8.8$ and $11.3 \mathrm{~m}$ ) and in the Schöhsee, without a deep-water chlorophyll maximum, from 1, 5 and $12 \mathrm{~m}$. The water was prefiltered through a $30-\mu \mathrm{m}$ mesh sieve, to remove larger zooplankton and inedible algae, and used to fill the reservoirs of the flow-through systems. These reservoirs were placed in the dark to avoid photosynthesis, and stirred continuously to prevent sedimentation.

Third brood neonates of mothers acclimated to standard conditions (12: 12 light : dark photoperiod, $1 \mathrm{mg} \mathrm{C} \mathrm{L}{ }^{-1}$, Oberer Arosasee $18{ }^{\circ} \mathrm{C}$, Schöhsee $20^{\circ} \mathrm{C}$ ) were collected within $12 \mathrm{~h}$ after birth. At the start of the experiment, 10 neonates were transferred to each of four preweighed aluminium weighing boats. The boats were dried overnight at $60^{\circ} \mathrm{C}$, cooled in a desiccator and weighed to the nearest $0.1 \mu \mathrm{g}$ with an ultramicrobalance. This provided the initial dry weight per animal. Five neonates were placed in each flow-through vessel and provided with lake water (seston) from the different depths. In the Oberer Arosasee we used nine replicates per depth and in the Schöhsee three replicates per depth. After 3 days, these animals were removed from the vessels and placed in preweighed aluminium boats, dried and weighed. All animals of a vessel were pooled to reduce measurement errors. Dry weights were converted into somatic growth rates per day using the formula

$$
g_{\mathrm{j}}=\left[\ln \left(W_{3}\right)-\ln \left(W_{0}\right)\right] / 3,
$$

where $W_{0}$ is the mass of the animals at day zero, $W_{3}$ the mass at the end of the experiment and 3 is the duration of an experiment in days. Juvenile growth rate was used as a measure of fitness, as it is strongly correlated to the intrinsic rate of population increase (Lampert \& Trubetskova, 1996). Juvenile growth rates were corrected for in situ temperatures, using the relation between temperature and developmental time determined by Vijverberg (1980), under the assumption that somatic growth rates scale with temperature in a similar way.

\section{Results}

Vertical profiles in the lakes

In the Oberer Arosasee, a distinct thermocline was absent and vertical temperature gradients were weak 


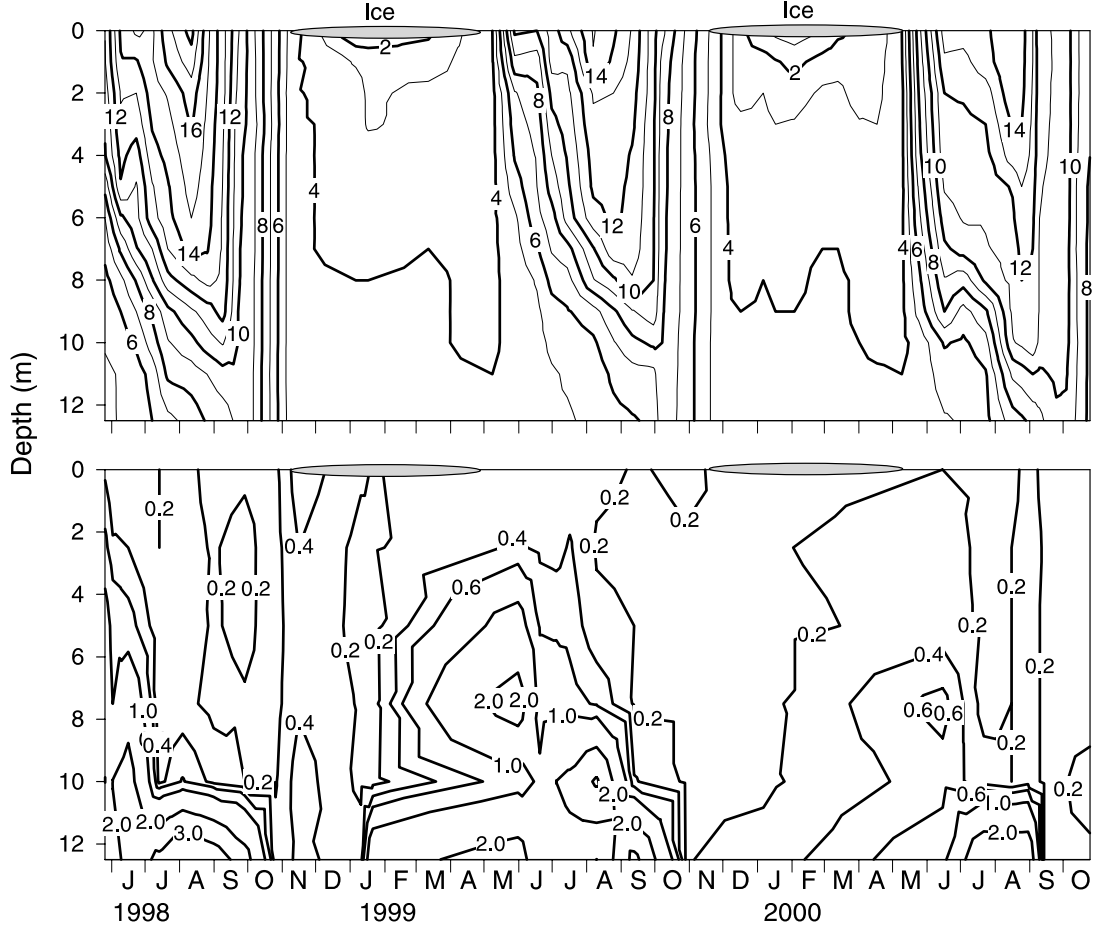

Fig. 1 Isopleth plots of temperature $\left({ }^{\circ} \mathrm{C}\right.$, top panel; POC $\mathrm{mg} \mathrm{L}^{-1}$, bottom panel) in the Lake Oberer Arosasee from May 1998 to October 2000.
(Fig. 1); the lake is dimictic with a 6-month period of ice cover. The POC accumulates in deep layers, especially during the summer months (up to $\left.3.6 \mathrm{mg} \mathrm{L}^{-1}\right)$. At this time, concentrations were low in surface waters $\left(\sim 0.2 \mathrm{mg} \mathrm{L}^{-1}\right)$. After the autumn turnover, POC was uniformly distributed throughout the water column (Fig. 1). The Schöhsee is a dimictic lake with a distinct thermocline during the summer months; the upper limit of the thermocline increased from $8 \mathrm{~m}$ in May to $10 \mathrm{~m}$ in October (Fig. 2). The POC concentrations were similar throughout the water column from April until October 1998 and between 0.7 and $0.4 \mathrm{mg} \mathrm{L}^{-1}$ (Fig. 2).

In the Oberer Arosasee, diatoms (mainly Cyclotella, Synedra) were the dominant phytoplankton species in spring; the summer phytoplankton consisted mainly of chrysophytes (mainly Cryptomonas and Rhodomonas), dinophytes (mainly Gymnodinium) and cyanobacteria (Microcystis, Pseudanabaena). Diatoms and chrysophytes (divers species) were the most abundant phytoplankton taxa from 0 to $10 \mathrm{~m}$ depths $(>90 \%)$. In the deepest strata, the amount of chlorophytes (Chlamydomonas), cryptophytes (Cryptomonas, Rhodomonas) and cyanobacteria (Pseudanabaena) increased (data not shown). Edible and inedible phytoplankton biomass increased with depth during the summer months (Fig. 3). During this period,

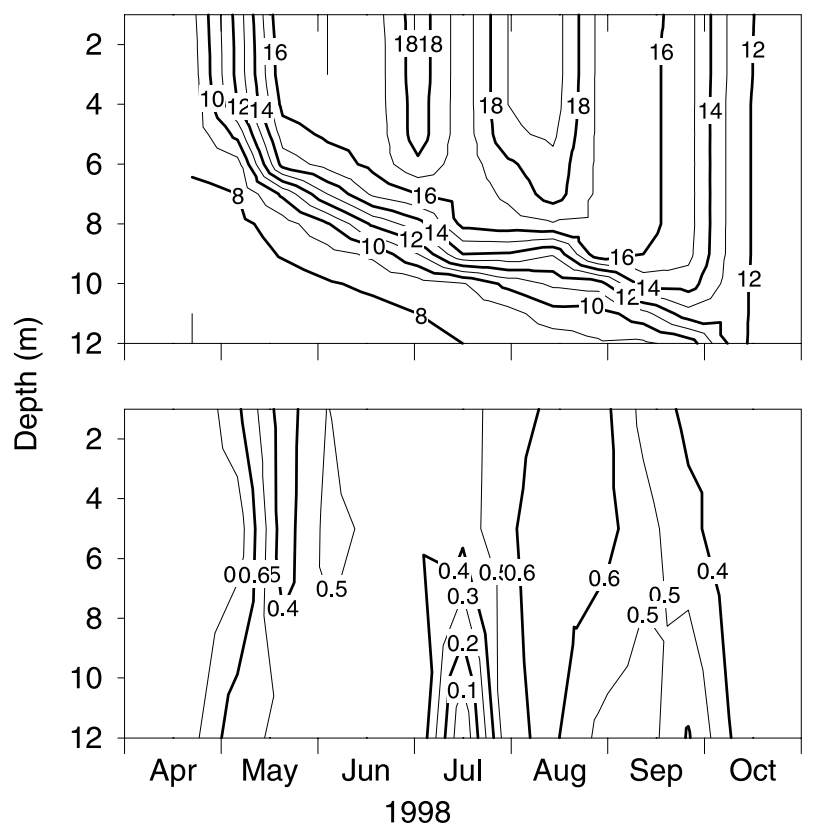

Fig. 2 Isopleth plots of temperature $\left({ }^{\circ} \mathrm{C}\right.$, top panel; $\mathrm{POC} \mathrm{mg} \mathrm{L}^{-1}$, bottom panel) in the Lake Schöhsee in 1998.

D. galeata stayed in deep layers during the day and moved to the surface waters at night (Fig. 3).

In the Schöhsee, edible phytoplankton biomass peaked slightly at $5 \mathrm{~m}$ depth and the inedible fraction increased with depth (Fig. 4). Chrysophytes (mainly

(C) 2003 Blackwell Publishing Ltd, Freshwater Biology, 48, 383-393 


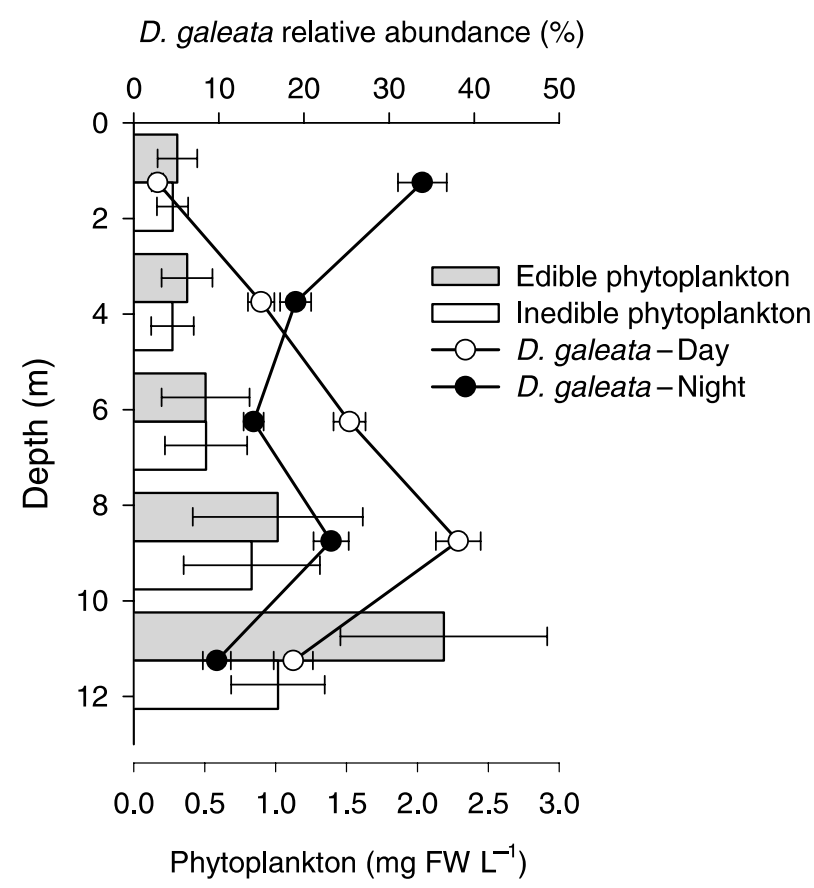

Fig. 3 Vertical distribution of adult Daphnia galeata relative abundance $(\%)$, and edible and inedible phytoplankton biomass (FW $=$ fresh weight) in the Oberer Arosasee during the summer 1998 (June 23-August 31). Error bars indicate standard errors.

Cryptomonas, Rhodomonas and Chrysochromalium) and cyanobacteria (mainly Chlorococcus, Aphanocystis and Coelospheria) dominated throughout the water column. During the day, daphniids (mainly D. galeata $x$ hyalina) stayed in deeper strata and a part of the population moved upwards at night (Fig. 4).

\section{Juvenile growth experiments}

In the Oberer Arosasee, we measured considerable differences in somatic growth rates of $D$. galeata when raised on water taken from different depths under constant temperature $\left(18{ }^{\circ} \mathrm{C}\right)$ for both experiments in July (Fig. 5), and we found a significant depth effect (Table 1). Daphnia galeata growth rate increased strongly in the two deepest water layers. At the time of the experiments, there was a weak temperature gradient and oxygen decreased strongly below $10 \mathrm{~m}$ depths. The POC concentrations of the seston increased and $\mathrm{C}: \mathrm{P}$ ratios decreased with depth (Fig. 5). Growth rate was strongly correlated with total POC $\left(r^{2}=0.83, P=0.003\right)$ and the POC fraction $<30 \mu \mathrm{m}\left(r^{2}=0.83 ; P=0.002\right)$ across depth and time.

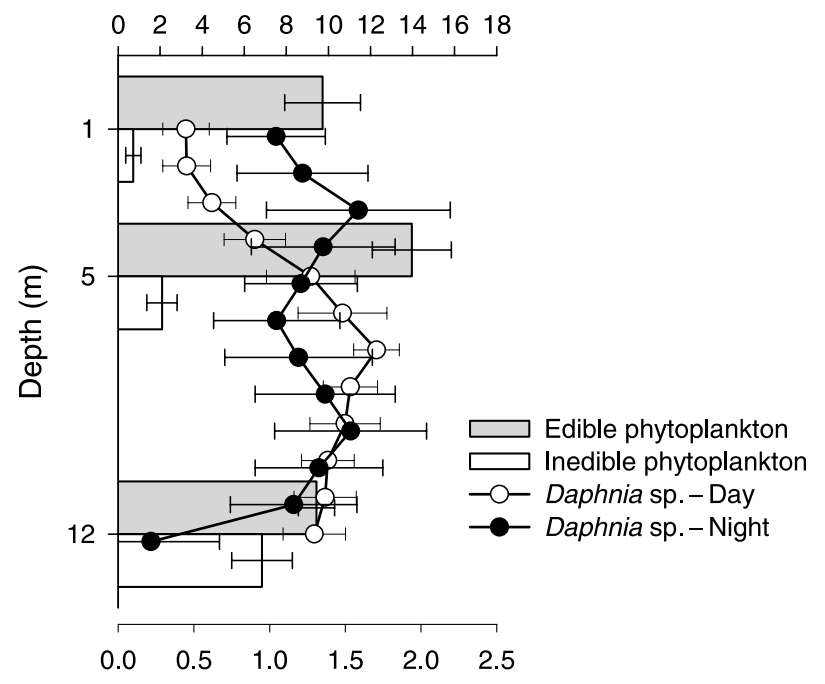

Phytoplankton abundance $\left(10^{6} \mathrm{Ind} . \mathrm{L}^{-1}\right)$

Fig. 4 Vertical distribution of adult Daphnia sp. relative abundance $(\%)$, and edible and inedible phytoplankton abundance (ind. $10^{6} \mathrm{~L}^{-1}$ ) in the Schöhsee during summer 1998 (June 3-August 26). Error bars indicate standard errors.

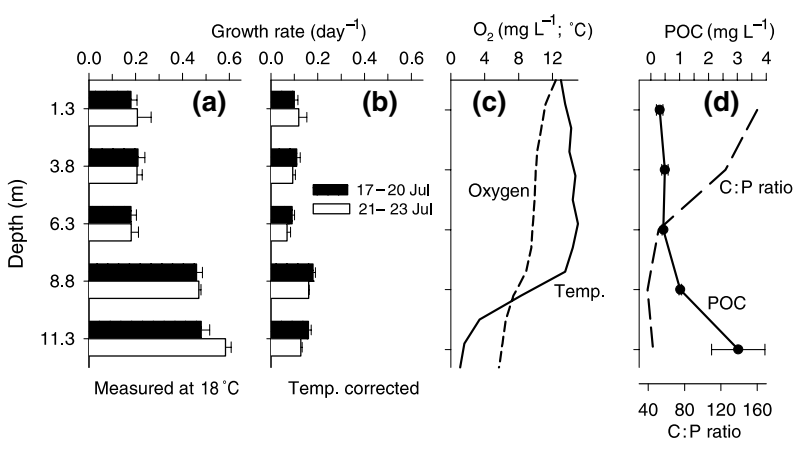

Fig. 5 Growth rates of Daphnia galeata cultured at $18{ }^{\circ} \mathrm{C}$ on lake seston collected from five different depths in the Oberer Arosasee in two periods in July 2001 (a). Growth rates are corrected for differences in temperature at the different depths in (b). Vertical profiles of temperature and oxygen (c), POC and C : P ratio (d) during the experiments. Error bars indicate standard errors.

After correction for the temperature differences in the different strata, we found a significant depth effect (Table 1). Temperature-corrected growth rates of the daphniids grown on seston from 8.8 and $11.3 \mathrm{~m}$ depths were significantly higher than those on seston from the upper depths (Fig. 5).

In the Schöhsee, growth conditions for daphniids were very similar among depths for the two dates in summer; POC values increased slightly at $5 \mathrm{~m}$ depth 


\begin{tabular}{|c|c|c|c|c|c|c|}
\hline & d.f. & MS & d.f. error & MS error & $\mathrm{F}$ & $P$ \\
\hline \multicolumn{7}{|l|}{ Raw values } \\
\hline \multicolumn{7}{|l|}{ Oberer Arosasee } \\
\hline Date & 1 & 0.0161 & 73 & 0.0085 & 1.90 & 0.17 \\
\hline Depth & 4 & 0.4510 & 73 & 0.0085 & 53.25 & $<0.001$ \\
\hline Date $\times$ depth & 4 & 0.0072 & 73 & 0.0085 & 0.86 & 0.50 \\
\hline \multicolumn{7}{|l|}{ Schöhsee } \\
\hline Date & 1 & 0.0001 & 12 & 0.0046 & 0.03 & 0.88 \\
\hline Depth & 2 & 0.0029 & 12 & 0.0046 & 0.64 & 0.54 \\
\hline Date $\times$ depth & 2 & 0.0001 & 12 & 0.0046 & 0.03 & 0.97 \\
\hline \multicolumn{7}{|c|}{ Temperature-corrected values } \\
\hline \multicolumn{7}{|c|}{ Oberer Arosasee } \\
\hline Date & 1 & 0.0023 & 73 & 0.0022 & 1.05 & 0.309 \\
\hline Depth & 4 & 0.028 & 73 & 0.0022 & 12.73 & $<0.001$ \\
\hline Date $\times$ depth & 4 & 0.0008 & 73 & 0.0022 & 0.38 & 0.823 \\
\hline \multicolumn{7}{|l|}{ Schöhsee } \\
\hline Date & 1 & 0.0006 & 12 & 0.0014 & 0.40 & 0.54 \\
\hline Depth & 2 & 0.0752 & 12 & 0.0014 & 52.53 & $<0.001$ \\
\hline Date $\times$ depth & 2 & 0.0001 & 12 & 0.0014 & 0.087 & 0.92 \\
\hline
\end{tabular}

Table 1 Summary ANOVA table of growth rates of experimental animals (raw and temperature-corrected values) as the dependent variable and date (random) and depth (fixed) as independent factors in the Oberer Arosasee and Schöhsee. Data are from two dates during the summer

d.f. - degrees of freedom, MS - mean square.

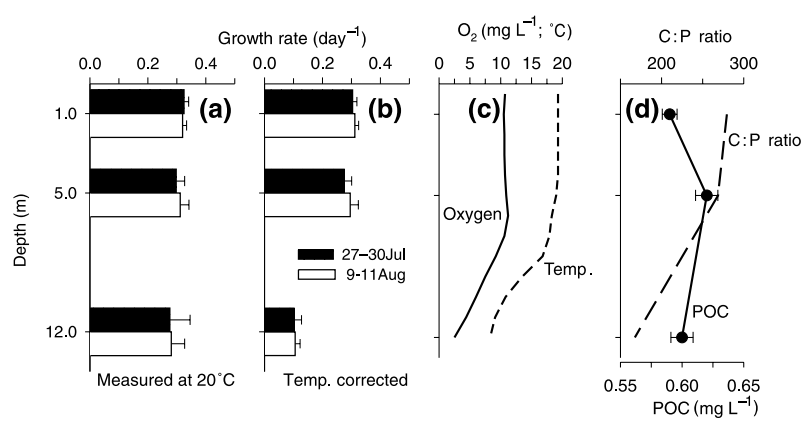

Fig. 6 Growth rates of Daphnia galeata $x$ hyalina cultured at $20{ }^{\circ} \mathrm{C}$ on lake seston collected from three different depths in the Schöhsee in two time periods in summer 1998 (a). Growth rates are corrected for differences in temperature at the different depths in (b). Vertical profiles of temperature and oxygen (c), POC and C : P ratio (d) during the experiments. Error bars indicate standard errors.

and the $\mathrm{C}: \mathrm{P}$ ratios decreased with depth (Fig. 6). We measured no significant effect of depth or date on growth rates (Table 1). After temperature correction, the depth effect was significant (Table 1) and temperature-corrected growth rates on seston collected at $12 \mathrm{~m}$ depth were significantly lower (Tukey post hoc comparison) than at 1 and $5 \mathrm{~m}$ (Fig. 6).

\section{Discussion}

In this study, we have shown that in summer, juvenile growth rates of Daphnia were not necessarily lower when fed seston from deep-water depth strata, both in populations from lakes with and without deep-water chlorophyll maxima. Our results are in agreement with the study of Williamson et al. (1996), who also measured higher reproductive rates in the metalimnion compared with the epilimnion in a lake with a deepwater chlorophyll maximum. These experiments provide evidence that in natural situations, growing conditions are not necessarily worsen in deeper strata compared with surface strata. In the Oberer Arosasee, deep-water food maxima were observed every summer over the 3-year study (Fig. 1) and the biomass of both edible and inedible phytoplankton increased with depth (Fig. 3). Growth rates of D. galeata were significantly higher in deeper strata compared with surface waters (Fig. 5), suggesting that food conditions in the deeper strata were better than in shallower strata. Quantitative food measurements (i.e. POC) explained a large part of the variation in $D$. galeata growth rate $(\sim 83 \%)$. In the Schöhsee, without a deep-water food maximum (Figs 2 and 4), growth rates of daphnids were not significantly different between depths (Fig. 6) and growth rates at $12 \mathrm{~m}$ were never lower during the growing season at standard temperature (Schöps, 1999). Also in this lake, seasonal changes in POC concentration explained a significant part of the variation in Daphnia growth rate (Boersma et al., 2001).

In addition to food quantity, the quality of seston is important in zooplankton production (Urabe et al., 
2002). In the Oberer Arosasee and Schöhsee, C : P values of the seston decreased with depth (Figs 5 and 6). Thus, P limitation of Daphnia growth was most likely in surface and middle strata in both lakes. But given the relative low seston $\mathrm{C}: \mathrm{P}$ values, especially in the Oberer Arosasee, the effect of $\mathrm{P}$ limitation on Daphnia growth rate was probably not very pronounced (Urabe, Clasen \& Sterner, 1997). Nevertheless, the increase in food quantity or quality may have led to better or equal growth conditions in the deep-water layers. Although several studies on Daphnia reported food-search behaviour of daphniids, with the animals swimming towards the highest densities of algae (Larsson \& Kleiven, 1996; Plath, 1999; W. Lampert, unpublished data), we observed that in the field, they did not show this behaviour. If the differences in growth rate were caused by quality differences, this could be explained if daphniids are unable to detect differences in food quality (but see Plath \& Boersma, 2001).

The growth experiments were carried out at 18 or $20{ }^{\circ} \mathrm{C}$ and not at in situ temperatures. By computing the temperature-corrected growth rates, we were able to estimate the effects of the temperature differences in the different strata. Comparisons between raw and temperature-corrected rates showed that temperature indeed played an important role. In the Schöhsee, the temperature gradient was strong, and after temperature correction, growth rates of animals fed seston from shallow depths were higher compared with seston from the deep-water layer (Fig. 6, Table 1). At night, a part of the Daphnia population migrated into the warmer surface waters (Fig. 4). In contrast, the Oberer Arosasee had a weak temperature gradient, and after temperature correction, the highest growth rates were still found in the deeper strata. Thus, according to the growth rates calculated on seston from the deeper strata in the Oberer Arosasee, daphniids should stay in deep water both day and night to maximise fitness. However, part of the $D$. galeata population migrated into the surface waters at night in this lake (Fig. 3). This upward migration was observed each summer during the 3-year study (Winder, 2002). This nocturnal upward migration in the Oberer Arosasee contradicts the hypothesis that migration occurs only when increased food levels at the surface make upward migration worthwhile, as suggested by Gliwicz \& Pijanowska (1988). These authors showed that in lakes with fish, a weak temperature gradient and a high food concentration in deep waters that Daphnia stayed in deep waters both day and night. The upward migration of $D$. galeata at night in the Oberer Arosasee might reflect avoidance of unknown costs of staying in the deep-water refuge. The intriguing question that remains is, what are these costs and why do D. galeata move into surface waters at night if growing conditions are more favourable in the deep layers?

First of all, there are two aspects of our methodology, which could contribute to the explanation. First, we removed many of the inedible algae in our growth experiments by filtering the water to remove other zooplankters, hence, inedible algae could not interfere with feeding (Gliwicz, 1990). Especially in the Schöhsee, filamentous cyanobacteria were abundant during the experiment, whereas in the Oberer Arosasee, large-sized diatoms and chlorophytes dominated the inedible taxa. Therefore, it could be that we overestimated growth, especially at depths where the ratio between edible and inedible algae is low, as was the case in the Schöhsee at $12 \mathrm{~m}$ depth (Schöps, 1999). Secondly, to correct growth rates measured at laboratory temperatures with the ambient temperatures we used the formula from Vijverberg (1980). However, several temperature functions have been proposed to calculate egg development time of daphniids in relation to temperature, some of them are plotted in Fig. 7 (Bottrell, 1975; Munro \& White, 1975; Bottrell et al., 1976). Egg development time of D. galeata from the Oberer Arosasee measured in a laboratory experiment at 7 and $14{ }^{\circ} \mathrm{C}$ (S. Lass, unpublished data) was within the range of the other functions (Fig. 7). If we assume that the growth rates in the different depths need to be at least identical to make it worthwhile for the daphniids to migrate upwards at night, we can compute the temperature correction necessary to achieve this. This function of egg development time with temperature has been added to the ones shown in Fig. 7. It is clear that this function is far outside the range of the other functions. Especially at higher temperature, egg development time should be much faster compared with the other functions. In addition, $Q_{10}$ of the hypothetical function was outside what have been measured in biological systems (Fig. 7 legend; Krogh, 1914). Therefore, it is very unlikely that the exact form of the temperature curve chosen here affected our results. 


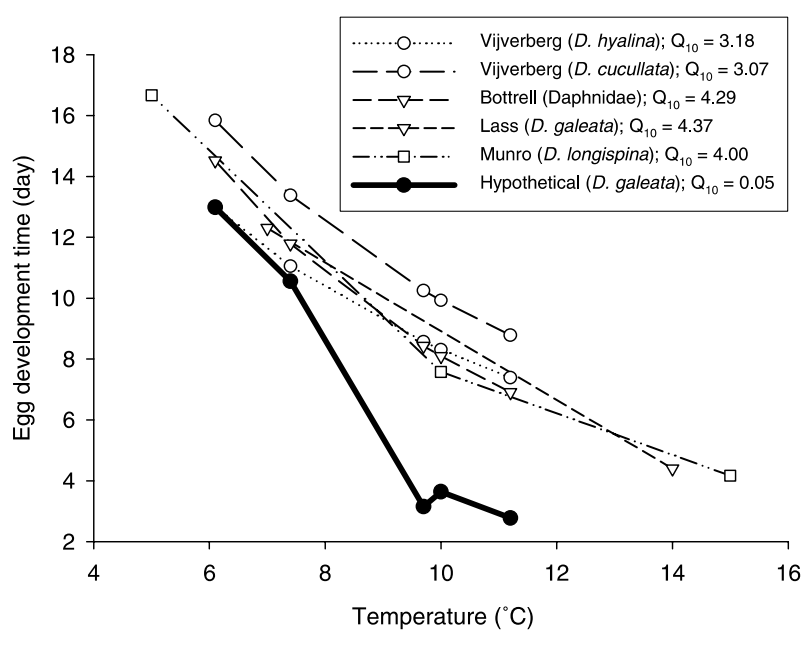

Fig. 7 The duration of egg development at various temperatures for Daphnia spp. reported in the literature. Daphnidae (Bottrell et al., 1976); Daphnia galeata (S. Lass, unpublished data), Daphnia longispina (Munro \& White, 1975); Daphnia cucullata and Daphnia hyalina (Vijverberg, 1980). Hypothetical egg development times of $D$. galeata that would give equal growth for the different depth strata for our experiments in the Oberer Arosasee. For each function $Q_{10}$ was calculated between the temperature range of 5 and $15{ }^{\circ} \mathrm{C}$ (for formula see Bottrell, 1975).

To achieve equal growth rates in the different depths in the Oberer Arosasee, the temperature difference between the surface and deepest depth should be $\sim 9{ }^{\circ} \mathrm{C}$, with a steep temperature gradient (e.g. $\sim 13{ }^{\circ} \mathrm{C}$ in the upper three depth strata and $\sim 4{ }^{\circ} \mathrm{C}$ in the deeper strata). In the Oberer Arosasee, the average difference during the summer months between the surface and deepest depth is $\sim 8{ }^{\circ} \mathrm{C}$; however, the gradient is weak (Fig. 1). Nevertheless, the higher temperature in surface waters might be important for the development of eggs in the D. galeata population. It could be that the temperature effect is different for juvenile growth rate and egg development. For developing eggs warm water conditions may be very important, thus migration into warmer surface waters might be a useful strategy to maximise fitness in the absence of light-dependent mortality risk, which are in surface waters at night.

Nocturnal migration into warmer water at night after feeding on benthic prey species was observed in larval fish species (Wurtsbaugh \& Neverman, 1988). The upward migration promoted digestion, thereby allowing greater feeding and growth and resulted in three times faster growth than if they had remained in the cold hypolimnion. For Daphnia, Haney \& Hall (1975) observed an increase in filtering rate per individual Daphnia up to 10-fold at night in warmer surface waters. In contrast, Lampert \& Taylor (1985) report no rhythmic feeding behaviour and no differences in filtration rates per unit biomass between day and night for Daphnia in Schöhsee. Grazing experiments in the Oberer Arosasee indicated no difference in the community grazing rate per unit biomass (M. Winder, unpublished data), suggesting that migration patterns can not be explained by diel rhythms in grazing activity. Feeding rates are linked to temperature and also to ambient food concentration (Beisner, McCauley \& Wrona, 1997; Plath, 1999); filtration rates decrease at lower temperature and food quantity. Orcutt \& Porter (1983) showed that food and temperature have a synergistic effect on Daphnia growth, i.e. Daphnia responded stronger when food and temperature was increased. Therefore, our temperature-corrected values may have overestimated the growth rates during our experiments, especially for seston from the deep strata of the Oberer Arosasee.

A number of alternative reasons could exist for the observed vertical migration behaviour in the Oberer Arosasee. In the Oberer Arosasee, Cyclops abyssorum, the only predaceous zooplankter, may influence to the vertical migration behaviour of D. galeata. However, this copepod species also exhibits a nocturnal DVM behaviour with mean day and night depths similar to D. galeata (M. Winder, unpublished data). If D. galeata migrates to avoid predation from $C$. abyssorum, it should have a different migration behaviour (Ohman, Frost \& Cohen, 1983). Avoidance of nocturnally predaceous invertebrates like Chaoborus may result in a reverse migration behaviour of the prey species (Neill, 1990); however, induction of DVM by copepods has not yet been observed.

In addition, low oxygen concentrations can restrict the vertical distribution of Daphnia (Wright \& Shapiro, 1990), although some species can counteract low oxygen concentration to a certain extent by producing haemoglobin (Sell, 1998). In the Oberer Arosasee, an anoxic layer develops below $10 \mathrm{~m}$ depth during the summer months. The anoxic area, however, did not prevent the daphniids from inhabiting the $10-12.5 \mathrm{~m}$ depth stratum, suggesting that they are highly tolerant to oxygen deficiency. Weider \& Lampert (1985) observed that Daphnia pulex species were able to regulate oxygen metabolism across a wide range of ambient oxygen concentrations, but below a critical oxygen concentration level of $3.5 \mathrm{mg} \mathrm{L}^{-1}$, filtering and 
respiration rates in D. pulex decreased dramatically. A low oxygen layer may serve as a refuge from fish predation (Hanazato, 1992) in that fish are obligate aerobic animals. However, haemoglobin production requires energy and low oxygen concentrations are unfavourable for reproduction, thus influencing lifehistory traits such as a reduction in juvenile growth rates (Hanazato, 1995). The oxygen concentration in the Oberer Arosasee can explain, to a certain extent, the migration out of the deeper strata, but not the upward migration above $8 \mathrm{~m}$ depth, as above-thatlayer oxygen concentrations and saturation were always beyond $8 \mathrm{mg} \mathrm{L}^{-1}$ and $85 \%$, respectively, during summer (Fig. 5).

In conclusion, our growth experiments showed that food availability for Daphnia in deep waters can be as good as in surface strata in lakes with and without deep-water chlorophyll maxima. Therefore, temperature appears to be the main cost for staying in deep refuge in lakes with a steep temperature gradient. However, also in a lake with a weak temperature gradient but overall low temperatures daphniids migrated upwards at night and may benefit from warmer temperatures to optimise fitness in the absence of light-dependent mortality risks. This indicated that the conditions in surface waters make upward migration worthwhile, even when food quantity and quality is decreasing. The main cause for this phenomenon still needs to be clarified.

\section{Acknowledgments}

We are grateful to Barbara Keller and Sandra Lass who provided valuable assistance in the field and during the experiment in the Oberer Arosasee and to Claudia Schöps for her help with the experiment in the Schöhsee. We also thank Richard Illi for analysing the water samples and Regula Illi for identifying and counting the algae. We thank James Ward, Winfried Lampert and Bill DeMott for their comments on earlier versions of this manuscript. This research was made possible by the EU (contract ENV4-CT97-0402) within the framework of the European Commission's Environment and Climate Programme and part of the project network WATER (Wetland and Aquatic Ecosystem Research). Financial support was provided by a grant from the Swiss Federal Office for Education and Science (No. 97.0040) and by a grant from the German Science Foundation to MB (BO 1488/3).

\section{References}

Beisner B.E., McCauley E. \& Wrona F.J. (1997) The influence of temperature and food chain length on plankton predator prey dynamics. Canadian Journal of Fisheries and Aquatic Sciences, 54, 586-595.

Bennett S.J., Sanders R.W. \& Porter K.G. (1990) Heterotrophic, autotrophic, and mixotrophic nanoflagellates: seasonal abundances and bacterivory in a eutrophic lake. Limnology and Oceanography, 35, 1821-1832.

Boersma M. \& Vijverberg J. (1995) Synergistic effects of different food species on life-history traits of Daphnia galeata. Hydrobiologia, 307, 109-115.

Boersma M., Schöps C. \& McCauley E. (2001) Nutritional quality of seston for the freshwater herbivore Daphnia galeata $x$ hyalina: biochemical versus mineral limitations. Oecologia, 129, 342-348.

Bottrell H.H. (1975) The relationship between temperature and duration of egg development in some epiphytic Cladocera and Copepoda from the River Thames, Reading, with a discussion of temperature functions. Oecologia, 18, 63-84.

Bottrell H.H., Duncan A., Gliwicz Z.M., Grygierek E. \& Herzig A. (1976) A review of some problems in zooplankton production studies. Norwegian Journal of Zoology, 24, 419-456.

Bürgi H.R. (1983) Eine neue Netzgarnitur mit KippSchliessmechanismus für quantitative Zooplanktonfänge in Seen. Schweizerische Zeitschrift für Hydrologie, 45, 505-507.

Conover R.J. \& Mayzaud P. (1984) Utilization of phytoplankton by zooplankton during the spring bloom in a Nova Scotia inlet. Canadian Journal of Fisheries and Aquatic Sciences, 41, 232-244.

DeMott W.R. \& Kerfoot W.C. (1982) Competition among cladocerans: nature of the interaction between Bosmina and Daphnia. Ecology, 63, 1949-66.

Elser J.J., Hayakawa K. \& Urabe J. (2001) Nutrient limitation reduces food quality for zooplankton: Daphnia response to seston phosphorus enrichment. Ecology, 82, 898-903.

Fee E.J. (1976) The vertical and seasonal distribution of chlorophyll in lakes of the Experimental Lakes Areas, nothwestern Ontario: implications for primary production estimates. Limnology and Oceanography, 21, 767-783.

Gabriel W. \& Thomas B. (1988) Vertical migration of zooplankton as an evolutionary stable strategy. American Naturalist, 132, 199-216.

Geller W. (1986) Diurnal vertical migration of zooplankton in a temperate great lake (L. Constance): a starvation avoidance mechanism? Archiv für Hydrobiologie, 74 (Suppl.), 1-60. 
Gliwicz Z.M. (1986) Predation and the evolution of vertical migration in zooplankton. Nature, 320, 746-748.

Gliwicz Z.M. (1990) Why do cladocerans fail to control algal blooms? Hydrobiologia, 200/201, 83-97.

Gliwicz Z.M. \& Pijanowska J. (1988) Effect of predation and resource depth distribution on vertical migration of zooplankton. Bulletin of Marine Science, 43, 695-709.

Hanazato T. (1992) Direct and indirect effects of lowoxygen layers on lake zooplankton communities. Archiv für Hydrobiologie, Beiheft Ergebnisse der Limnologie, 35, 87-98.

Hanazato T. (1995) Life history responses of two Daphnia species of different sizes against a fish kairomone. Japanese Journal of Limnology, 56, 27-32.

Haney J.F. \& Hall D.J. (1975) Diel vertical migration and filter-feeding activities of Daphnia. Archiv für Hydrobiologie, 75, 413-441.

Infante V.A. (1973) Untersuchungen über die Ausnutzbarkeit verschiedener Algen durch das Zooplankton. Archiv für Hydrobiologie Suppl., 42, 340-405.

Kasprzak P.H., Gervais F., Adrian R. et al. (2000) Trophic characterization, pelagic food web structure and comparison of two mesotrophic lakes in Brandenburg (Germany). International Review of Hydrobiology, 85, 167189.

Kerfoot W.C. (1985) Interactions among cladocerans: food limitation and exploitative competition. Archiv für Hydrobiologie, Beiheft Ergebnisse der Limnologie, 21, 431-451.

Krogh A. (1914) On the influence of the temperature on the rate of embryonic development. Zeitschrift für Allgemeine Physiologie, 16, 163-177.

Lampert W. (1988) The relative importance of food limitation and predation in the seasonal cycle of two Daphnia species. Verhandlungen Internationale Vereinigung für Theoretische und Angewandte Limnologie, 23, 713718.

Lampert W. (1989) The adaptive significance of diel vertical migration of zooplankton. Functional Ecology, 3, 21-28.

Lampert W. (1993) Ultimate causes of diel vertical migration of zooplankton: new evidence for the predator avoidance hypothesis. Archiv für Hydrobiologie, Beiheft Ergebnisse der Limnologie, 39, 79-88.

Lampert W. \& Taylor B.E. (1985) Zooplankton grazing in a eutrophic lake: implications of diel vertical migration. Ecology, 66, 68-82.

Lampert W. \& Trubetskova I. (1996) Juvenile growth rate as a measure of fitness in Daphnia. Functional Ecology, 10, 631-635.

Lampert W., Schmitt R.D. \& Muck P. (1988) Vertical migration of freshwater zooplankton: test of some hypotheses predicting a metabolic advantage. Bulletin of Marine Science, 43, 620-640.

Larsson P. \& Kleiven O.T. (1996) Food search in Daphnia. In: Zooplankton: Sensory Ecology and Physiology (Eds P.H. Lenz, D.K. Hartline, J.E. Purcell \& D.L. Macmillan), pp. 375-387. Gordon and Breach, Amsterdam.

Loose C.J. \& Dawidowicz P. (1994) Trade-offs in diel vertical migration by zooplankton: the costs of predator avoidance. Ecology, 75, 2255-2263.

Müller-Navarra D. \& Lampert W. (1996) Seasonal patterns of food limitation in Daphnia galeata: separating food quantity and food quality effects. Journal of Plankton Research, 18, 1137-1157.

Munro I.G. \& White R.W.G. (1975) Comparison of the influence of temperature on the egg development and growth of Daphnia longispina O. F. Müller (Crustacea: Cladocera) from two habitats in Southern England. Oecologia, 20, 157-165.

Neill W.E. (1990) Induced vertical migration in copepods as a defence against invertebrate predation. Nature, $345,524-525$.

Ohman M.D., Frost B.W. \& Cohen E.B. (1983) Reverse diel vertical migration: an escape from invertebrate predators. Science, 220, 1404-1407.

Orcutt J.D. \& Porter K.G. (1983) Diel vertical migration by zooplankton: constant and fluctuating temperature effects on life history parameters of Daphnia. Limnology and Oceanography, 28, 720-730.

Pijanowska J., Weider L.J. \& Lampert W. (1993) Predatormediated genotypic shifts in a prey population experimental evidence. Oecologia, 96, 40-42.

Plath K. (1999) Filtrierverhalten von Daphnia: Anpassung an die Variabilität des Habitats. Thesis, Universität Kiel, Germany.

Plath K. \& Boersma M. (2001) Mineral limitation of zooplankton: stoichiometric constraints and optimal foraging. Ecology, 82, 1260-1269.

Porter K.G. (1973) Selective grazing and differential digestion of algae by zooplankton. Nature, 244, 179180.

Ringelberg J. (1999) The photobehaviour of Daphnia spp. as a model to explain diel vertical migration in zooplankton. Biological Reviews of the Cambridge Philosophical Society, 74, 397-423.

Ringelberg J., Flik B.G.J., Lindenaar D. \& Royackers K. (1991a) Diel vertical migration of Daphnia hyalina (sensu latiori) in Lake Maarsseveen: Part 2. Aspects of population dynamics. Archiv für Hydrobiologie, 122, 385-401.

Ringelberg J., Flik B.G.J., Lindenaar D. \& Royackers K. (1991b) Diel vertical migration of Daphnia hyalina (sensu latiori) in Lake Maarsseveen: Part: 1. Aspects 
of seasonal and daily timing. Archiv für Hydrobiologie, 121, 129-145.

Rott E. (1981) Some results from phytoplankton counting inter calibration. Schweizerische Zeitschrift für Hydrologie, 43, 34-62.

Schöps C. (1999) Einfluß der Nahrungsqualität auf das Wachstum von Daphnia sp. Diplomarbeit, Universität Kiel, Germany.

Sell A.F. (1998) Adaptation to oxygen deficiency: contrasting patterns of haemoglobin synthesis in two coexisting Daphnia species. Comparative Biochemistry and Physiology, 120, 119-125.

Stich H.B. (1989) Seasonal changes of diel vertical migration of crustacean plankton in Lake Constance. Archiv für Hydrobiologie, Monographische Beiträge, 3, 355-405.

Stich H.B. \& Lampert W. (1981) Predator evasion as an explanation of diurnal vertical migration by zooplankton. Nature, 293, 396-398.

Tilzer M. \& Schartz K. (1976) Seasonal and vertical pattern of phytoplankton light adaptation in a high mountain lake. Archiv für Hydrobiologie, 77, 488-504.

Uehlinger U. \& Bloesch J. (1987) Variatio in the C : P ratio of suspended and settling seaston and its significance for P uptake calculations. Freshwater Biology, 17, 99-108.

Uehlinger U., Bossard P., Bloesch P., Bürgi H.R. \& Bührer H. (1984) Ecological experiments in limnocorrals: methodological problems and quantification of the epilimnetic phosphorus and carbon cycles. Verhandlungen Internationale Vereinigung für Theoretische und Angewandte Limnologie, 22, 163-171.

Urabe J., Clasen J. \& Sterner R.W. (1997) Phosphorus limitation of Daphnia growth: is it real? Limnology and Oceanography, 42, 1436-1443.
Urabe J., Kyle M., Makino W., Yoshida T., Andersen T. \& Elser J.J. (2002) Reduced light increases herbivore production due to stoichiometric effects of light/nutrient balance. Ecology, 83, 619-627.

Vijverberg J. (1980) Effect of temperature in laboratory studies on development and growth of Cladocera and Copepoda from Tjeukemeer, The Netherlands. Freshwater Biology, 10, 317-340.

Weider L.J. \& Lampert W. (1985) Differential response of Daphnia genotypes to oxygen stress: respiration rates, hemoglobin content and low-oxygen tolerance. Oecologia, 65, 487-491.

Williamson C.E., Sanders R.W., Moeller R.E. \& Stutzman P.L. (1996) Utilization of subsurface food resources for zooplankton reproduction: implications for diel vertical migration theory. Limnology and Oceanography, 41, 224-233.

Winder M. (2002) Zooplankton ecology in high-mountain lakes. Thesis, Swiss Federal Institute for Environmental Science and Technology (ETH), Zürich, Switzerland.

Winder M. \& Spaak P. (2001) Carbon as an indicator of Daphnia condition in an alpine lake. Hydrobiologia, 442, 269-278.

Wright D. \& Shapiro J. (1990) Refuge availability: a key to understand the summer disappearance of Daphnia. Freshwater Biology, 24, 43-62.

Wurtsbaugh W.A. \& Neverman D. (1988) Post-feeding thermotaxis and daily vertical migration in a larval fish. Nature, 333, 846-848.

Zaret T.M. (1980) Predation and Freshwater Communities. Yale University Press, New Haven \& London.

(Manuscript accepted 11 September 2002) 